\title{
Comparison of the physicochemical profiles of buriti from the Brazilian Cerrado and the Amazon region
}

\author{
Thalita Lin Netto CÂNDIDO ${ }^{1}$, Mara Reis SILVA ${ }^{1 *}$
}

\begin{abstract}
Demand for native fruits has been expanding, due to the increasing interest in foods with possible health benefits. The buriti (Mauritia flexuosa L. f.) is a native Brazilian fruit, appreciated by local populations, and its products are already on the market. This study investigated the physical characteristics and nutritional composition of buriti pulp, obtained from typical Cerrado and Amazon regions in Brazil. These regions influenced physical parameters and chemical composition. The fruits originating in the Cerrado were bigger and heavier than the ones from the Amazon. Nevertheless, protein, fatty acid and carbohydrate contents were higher in fruits from the Amazon region. The analyzed buriti fruits presented high monounsaturated fatty acid concentration ( 73.03 to $79.43 \mathrm{~g} / 100 \mathrm{~g}$ ), with the predominance of oleic acid (72.21 to $78.57 \mathrm{~g} / 100 \mathrm{~g})$. Buriti fruits may be a promising source of good nutritional quality vegetable oil and dietary fiber.
\end{abstract}

Keywords: Mauritia flexuosa L. f.; nutritional value; fatty acids; minerals.

Practical Application: This work showed that the region influenced the physical parameters and chemical composition of buriti grown in Amazon and Cerrado.

\section{Introduction}

Brazil is noted for its fructiferous biodiversity, and the buriti is one of the most abundant fruits in Brazilian territory, presenting great environmental importance and a significant supply of products for rural populations. The moriche palm tree (Mauritia flexuosa L. f.) is from the Arecaceae family, and it may be found in regions ranging from the Amazon forest to the Cerrado (savannah) in several Brazilian states (Lorenzi et al., 2004). Its fruit, the buriti, has an especial color, flavor and aroma, being greatly appreciated by regional communities located in areas of high production (Darnet et al., 2011). However, trade in native fruits in Brazil has been expanding to metropolitan areas, due to the demand for natural foods with possible beneficial health effects (Oliveira et al., 2006).

The palm tree has high economic potential, and some studies have shown that buriti has strong nutritional potential and can be considered a functional food (Pineli et al., 2015). Buriti oil is an interesting alternative source of tocopherol, carotenoids and monounsaturated fatty acids (Melo et al., 2011).

The functional potential of buriti fruits is due in large part to the high levels of bioactive compounds such as carotenoids and total phenolics, which have an important antioxidant action and possible protective effect against free radical damage in the body (Manhães \& Sabaa-Srur, 2011; Koolen et al., 2013; Bataglion et al., 2014; Candido et al., 2015). However, there is a difference in the contents of chemical compounds as a function of the region of origin. This fact reinforces the need for research on native fruits, as a natural resource of chemical compounds, according to the producing regions (Candido et al., 2015).

The physical and chemical characterization of native fruits such as buriti, as well as the analysis of environmental influences on these characteristics, is also important for the sustainable use of native species and in order to support research on genetic improvement, handling and domestication of the species, as fruit harvesting is still based on extractivism. The potential nutritional knowledge adds value and quality to the product (Canuto et al., 2010).

Although there are some publications about the chemical composition of buriti fruit from the Amazon region, these data do not relate to fruit grown in the state of Goiás, central Brazil. Therefore, the objective of the present work was to evaluate the physical characteristics and nutritional composition of buriti fruits, obtained in two different Brazilian regions, the Cerrado and Amazon biomes.

\section{Materials and methods}

\subsection{Plant material and sample preparation}

Buriti fruits were obtained in two Brazilian biomes: the Amazon region and the Cerrado. The Amazon buriti was collected in the state of Pará $\left(06^{\circ} 19\right.$ 598' S; $\left.48^{\circ} 28668^{\prime} \mathrm{W}\right)$, altitude $127 \mathrm{~m}$, vegetation area with dense equatorial forests (temperature $23.1-33{ }^{\circ} \mathrm{C}$ ), precipitation and monthly average sunshine of $245.4 \mathrm{~mm}$ and 168 hours, respectively. The fruits 
from the Cerrado region were collected in the state of Goiás ( $16^{\circ} 53891^{\prime} \mathrm{S} ; 49^{\circ} 20065^{\prime} \mathrm{W}$ ), altitude $780 \mathrm{~m}$, savannah area with sub-humid tropical climate $\left(19.8-30^{\circ} \mathrm{C}\right)$, precipitation and monthly average sunshine of $80.1 \mathrm{~mm}$ and 174.2 hours, respectively. Climatic and geographic data were supplied by the National Institute of Meteorology, Brazil (Instituto Nacional de Meteorologia, 2012).

In each region, 90 to $120 \mathrm{~kg}$ of the fruit were collected. Fruits that showed no physical damage were selected for processing and were maintained, in the shade, at room temperature, on a single-layer flat surface for approximately three to five days after collection, until fully ripe. They were then submerged in water at room temperature, from 8 to 24 hours, to facilitate removal of the shell. Following the previous step, the fruits were peeled and pulped. Lastly, they were stored in polyethylene packages and kept at $-18{ }^{\circ} \mathrm{C}$ until the chemical analyses.

\subsection{Physical characterization}

In order to carry out physical characterization, 90 fruits from each studied region were weighed to verify their mass (g) on an analytical scale (BG8000, Gehaka, São Paulo, Brazil), and longitudinal and transverse diameters were measured with a digital paquimeter (500-144, 150 mm, Mitutoyo, São Paulo, Brazil). Pulp yield was determined by the relationship between pulp mass and total fruit mass.

Pulp color was analyzed using Color Quest II colorimeter (Sphere) (Hunter Lab Reston, Virginia, United States), mode CIE $L^{*}, a^{*}, b^{*}$. From the $a^{*}$ and $b^{*}$ values, color angle $\left(h^{\circ}\right)$ and chromaticity $\left(C^{*}\right)$ of the pulps were calculated through the formulas: $\mathrm{h}^{\circ}=\tan ^{-1}\left(\mathrm{~b}^{\star} / \mathrm{a}^{\star}\right)$ and $\mathrm{C}^{\star}=\left(\mathrm{a}^{\star 2}+\mathrm{b}^{\star 2}\right)^{1 / 2}$, respectively (McGuire, 1992).

\subsection{Proximate analysis and caloric value}

Moisture content of the fruits was determined by desiccation at $105^{\circ} \mathrm{C}$, until constant weight (Association of Official Analytical Chemists, 2005). Total fat content was quantified according to the methodology of Bligh \& Dyer (1959). Nitrogen content estimated by the Kjeldahl method (Association of Official Analytical Chemists, 2005) was converted to protein content by using the conversion factor 6.25 . Total dietary fiber was analyzed by enzymatic gravimetric method (Association of Official Analytical Chemists, 2005), and the ash content was determined by incineration in a muffle furnace at $550{ }^{\circ} \mathrm{C}$ (Association of Official Analytical Chemists, 2005). The content of carbohydrates was calculated by difference. The caloric value was estimated using the conversion factors of 4,4 and 9 for protein, carbohydrate and lipids, respectively.

\subsection{Mineral analysis}

After the incineration of buriti samples at $550{ }^{\circ} \mathrm{C}$, the minerals were extracted from the ash with concentrated hydrochloric acid. After that, they were quantified by atomic absorption spectrophotometry (Perkin Elmer, Analyst 200, Whaltman, United States) (Association of Official Analytical Chemists, 1998).

\subsection{Fatty acid analysis}

The lipids from buriti pulp were extracted by the method described by Bligh \& Dyer (1959). Later, they were esterified according to Hartman \& Lago (1973) and the fatty acids were analyzed in a CGC Agilent 6850 Series GC System capillary gas chromatograph (Agilent Technologies, Santa Clara, California, United States). The methyl esters of fatty acids were separated according to the procedure of American Oil Chemists' Society (2009) in a DB-23 Agilent capillary column (50\% Cyanopropyl-methylpolysiloxane), with dimensions of $60 \mathrm{~m} \times 0.25 \mathrm{~mm}$ inner $\times 0.25 \mu \mathrm{m}$ film. The operating conditions of the chromatograph were as follows: column flow $=1.0 \mathrm{~mL} / \mathrm{min}$, linear velocity $=24 \mathrm{~cm} / \mathrm{s}$; detector temperature $=280^{\circ} \mathrm{C}$, injector temperature $=250^{\circ} \mathrm{C}$, oven temperature $=110-215^{\circ} \mathrm{C}\left(5^{\circ} \mathrm{C} / \mathrm{min}\right)$, $215^{\circ} \mathrm{C}-24 \mathrm{~min}$, carrier gas - helium; injection volume $=1.0 \mu \mathrm{L}$.

\subsection{Statistical analysis}

Results were expressed as mean \pm standard deviation. Means were compared through Student's t-test and the 5\% significance level was chosen as standard. Calculations were performed with software Statistica 7.0 (Statsoft Inc., Tulsa, United States).

\section{Results and discussion}

\subsection{Physical characteristics of buriti fruits}

The buriti fruits originating from the Cerrado presented higher diameters, mass and yield (Table 1) when compared to the ones obtained in the Amazon. Barbosa et al. (2010) observed longitudinal diameter and transverse diameter $(43 \mathrm{~mm}$ and $37.1 \mathrm{~mm}$ respectively), values close to the ones found for the Amazon region, while analyzing the physical characteristics of buriti fruits from five matrices of an eco-region from the same biome.

The fruits from the Cerrado region presented a bright yellow tone, whereas the ones from the Amazon had a more intense dark yellow and red color (Table 1). Similar color characteristics were also attributed to Amazon buritis in the study conducted by Canuto et al. (2010). These authors also reported fruits with

Table 1. Physical characteristics and color parameters of buriti fruits from two biomes of Brazil.

\begin{tabular}{lcc}
\hline \multirow{2}{*}{ Characteristics $^{1}$} & \multicolumn{2}{c}{ Biome } \\
\cline { 2 - 3 } & Cerrado (Goiás) & Amazon (Pará) \\
\hline Longitudinal diameter $(\mathrm{mm})$ & $57.39 \pm 2.31^{\mathrm{a}}$ & $44.81 \pm 2.00^{\mathrm{b}}$ \\
Transverse diameter $(\mathrm{mm})$ & $51.74 \pm 1.93^{\mathrm{a}}$ & $36.79 \pm 2.21^{\mathrm{b}}$ \\
Mass $(\mathrm{g})$ & $74.85 \pm 7.81^{\mathrm{a}}$ & $30.08 \pm 3.25^{\mathrm{b}}$ \\
Yield (\%) & $16.43 \pm 4.33^{\mathrm{a}}$ & $8.53 \pm 1.64^{\mathrm{b}}$ \\
Parameters of color & & \\
$\mathrm{L}^{\star}$ (Luminosity) & $50.21 \pm 0.02^{\mathrm{a}}$ & $49.51 \pm 0.12^{\mathrm{b}}$ \\
$\mathrm{a}^{*}$ (Red to green) & $23.28 \pm 0.07^{\mathrm{b}}$ & $27.41 \pm 0.06^{\mathrm{a}}$ \\
$\mathrm{b}^{*}$ (Yellow to blue) & $33.58 \pm 0.18^{\mathrm{a}}$ & $33.59 \pm 0.03^{\mathrm{a}}$ \\
$\mathrm{C}^{*}$ (Chromaticity) & $40.86 \pm 0.11^{\mathrm{b}}$ & $43.35 \pm 0.04^{\mathrm{a}}$ \\
$\mathrm{h}^{\circ}$ (Tone) & $55.26 \pm 0.22^{\mathrm{a}}$ & $50.78 \pm 0.07^{\mathrm{b}}$ \\
\hline
\end{tabular}

${ }^{1}$ Values are shown as mean \pm standard deviation $(n=90$, color $n=3)$. Means followed by the same letter within each line are not significantly different at $\mathrm{p}<0.05$. Student's $t$ test. ${ }^{2}$ Ratio between pulp mass and total mass of the fruits. 
a more distinguished yellow tone (70.8) than that observed in this study and similar luminosity (48.2) to that found in all studied regions.

The intensity of buriti color is probably related to carotenoid pigment concentration. According to the specialized literature, the buriti is an important source of carotenoids, particularly provitamin A carotenoid (Rodriguez-Amaya et al., 2008).

Visual appearance, especially color as a parameter of quality, influences consumers' acceptance and thus the successful commercialization of the fruits, since there is a strong relationship between visual and chromatic characteristics of foods and consumers' attraction to them (Iglesias et al., 2012). Thus, it is possible that sensory analysis studies show that Cerrado buritis are more attractive, due to their shiny yellow color.

The verified variability in physical characteristics between the studied buriti fruits may be justified by climatic and geographic differences in the two regions of origin. Buritis from the Cerrado were collected in the mid-western region of Brazil, in an area at high altitude and in a more agreeable temperature, whereas the fruits obtained from the Amazon region are native to the north of Brazil, with predominantly low altitudes and high temperatures. Therefore, the results of the physical evaluation of buriti reinforce the importance of studies on physical characteristics, with the objective of selecting and propagating species of greater viability.

\subsection{Composition in nutrients and caloric value}

Significant differences were found regarding the nutrient levels of both studied regions, except for total dietary fiber (Table 2). Buritis from the Cerrado presented higher moisture when compared to those from the Amazon region and to those reported for buritis collected in areas located in the Cerrado and Amazon biomes or the transition between the two (Melo et al., 2011). This diversity of results may be related to factors such as the commonly employed method of pulping the fruit, which involves water immersion, in addition to environmental factors inherent to climatic and geographic conditions.

Buritis obtained in the Amazon region presented higher protein, lipid and carbohydrate concentration when compared to the fruits from the Cerrado biome. The biggest difference was verified in the lipid content, since the Amazon buritis presented

Table 2. Chemical composition and caloric value of buriti pulp from two biomes of Brazil.

\begin{tabular}{lcc}
\hline \multicolumn{1}{c}{ Components } & \multicolumn{2}{c}{ Biome } \\
\cline { 2 - 3 }$\left(\mathrm{g} / 100\right.$ g of fresh weight) ${ }^{1}$ & Cerrado (Goiás) & Amazon (Pará) \\
\hline Moisture & $74.47 \pm 0.11^{\mathrm{a}}$ & $64.45 \pm 0.20^{\mathrm{b}}$ \\
Lipids & $6.15 \pm 0.26^{\mathrm{b}}$ & $14.28 \pm 0.39^{\mathrm{a}}$ \\
Proteins & $1.87 \pm 0.01^{\mathrm{b}}$ & $2.42 \pm 0.05^{\mathrm{a}}$ \\
Carbohydrates & $9.70 \pm 0.41^{\mathrm{b}}$ & $11.31 \pm 0.54^{\mathrm{a}}$ \\
Total dietary fiber & $6.69 \pm 0.08^{\mathrm{a}}$ & $6.61 \pm 0.01^{\mathrm{a}}$ \\
Ash & $1.12 \pm 0.04^{\mathrm{a}}$ & $0.93 \pm 0.01^{\mathrm{b}}$ \\
Energy (kcal/100 g) & 101.58 & 184.60 \\
\hline${ }^{ }$Values are shown as means \pm standard deviation $(\mathrm{n}=3$, except for fiber: $\mathrm{n}=4)$. Means \\
followed by the same letter within each line are not significantly different at $\mathrm{p}<0.05$. \\
Student's t-test.
\end{tabular}

approximately twice as much. This high value and the lower moisture content contributed to the higher energy value found in buritis from the Amazon region.

Manhães \& Sabaa-Srur (2011) reported lipid contents for the Amazon buritis close to those obtained in this study in the same region $(13.85 \mathrm{~g} / 100 \mathrm{~g})$. The higher lipid content of the fruits from the Amazon may contribute to a greater use of fruits from this region by the food, cosmetics and pharmaceutical industries, aiming at the utilization of buriti oil as a potential vegetable oil.

Another edible palm fruit from the Arecaceae family is the macaúba or coyol (Acrocomia aculeata Mart), widely distributed in Brazil, especially in the Cerrado region (Sanjinez-argandoña \& Chuba, 2011). Silva et al. (2008) reported lower moisture $(34.32 \mathrm{~g} / 100 \mathrm{~g})$ and higher fiber $(11.14 \mathrm{~g} / 100 \mathrm{~g})$ contents for the macaúba from the Cerrado in Goiás state, when compared to buritis from both regions analyzed; however, the contents of protein $(2.76 \mathrm{~g} / 100 \mathrm{~g})$ and lipids $(14.93 \mathrm{~g} / 100 \mathrm{~g})$ were similar. Although buriti and macaúba present some different concentrations of these compounds, the main characteristics of both are the high lipid and dietary fiber contents.

Buriti fruits from the Cerrado and the Amazon region were similar regarding fiber contents when compared to each other and also when compared to the value found in the literature $(6.89 \mathrm{~g} / 100 \mathrm{~g})$ for the Amazon buriti (Manhães \& Sabaa-Srur, 2011). Fiber contents of buritis from both regions were higher than citrus fruits, such as orange $(2.4 \mathrm{~g} / 100 \mathrm{~g})$, grapefruit $(1.6 \mathrm{~g} / 100 \mathrm{~g})$, tangerine $(1.8 \mathrm{~g} / 100 \mathrm{~g})$ and lime $(2.8 \mathrm{~g} / 100 \mathrm{~g})$ (Liu et al., 2012), as the approximate usual intake of $30 \mathrm{~g}$ of buriti pulp per day results in about $2.0 \mathrm{~g}$ of fiber.

Even though the Amazon buritis stood out in regard to most of the composition compounds, the ash content was higher for the Cerrado buriti. Possibly, soil characteristics from the Cerrado region have influenced the higher mineral concentrations, as described below in Mineral Composition.

Variations in chemical properties have been reported for several species of fruits cultivated in different regions (Borges et al., 2011; Liu et al., 2008). This fact confirms the data reported in this study, which suggest that the cultivation region's climatic and geographic conditions may influence the chemical composition of buriti fruits.

\subsection{Mineral composition}

Although the mineral content of buritis from both biomes reached no more than $11 \%$ of the Recommended Dietary Allowance (RDA) (Institute of Medicine, 2011, 2006), calcium concentration may be considered relevant for fruits, especially for the Cerrado buritis (Table 3), since the value was higher than that of strawberries, apples, peaches and gooseberries (Ekholm et al., 2007).

Calcium, zinc and copper contents of the fruits collected in the Cerrado were higher than those found for the Amazon ones. A previous study on mineral contents found in Cerrado fruits including buriti, reported lower calcium $(51.7 \mathrm{mg} / 100 \mathrm{~g})$, zinc $(0.4 \mathrm{mg} / 100 \mathrm{~g})$ and magnesium $(17.0 \mathrm{mg} / 100 \mathrm{~g})$ contents in relation to those reported in this study for the same region 
Table 3. Mineral composition of buriti pulp from two biomes of Brazil, and percentage of intake according to the reference values.

\begin{tabular}{|c|c|c|}
\hline \multirow{2}{*}{$\begin{array}{c}\text { Minerals } \\
\text { (mg/100 g of fresh weight })\end{array}$} & \multicolumn{2}{|c|}{ Biome $^{1}$} \\
\hline & Cerrado (Goiás) & Amazon (Pará) \\
\hline $\mathrm{Ca}$ & $89.12 \pm 0.04^{\mathrm{a}}$ & $44.12 \pm 0.01^{\mathrm{b}}$ \\
\hline $\operatorname{RDA}(\%)^{2}$ & 8.91 & 4.41 \\
\hline $\mathrm{Fe}$ & $0.40 \pm 0.00^{b}$ & $0.49 \pm 0.00^{a}$ \\
\hline RDA (\%) & 5.0 & 6.12 \\
\hline $\mathrm{Na}$ & $2.15 \pm 0.00^{\mathrm{a}}$ & $2.14 \pm 0.00^{\mathrm{a}}$ \\
\hline $\mathrm{AI}(\%)^{3}$ & 0.14 & 0.14 \\
\hline $\mathrm{K}$ & $218.40 \pm 0.12^{\mathrm{a}}$ & $210.98 \pm 0.27^{a}$ \\
\hline $\mathrm{AI}(\%)$ & 4.64 & 4.48 \\
\hline $\mathrm{Zn}$ & $0.69 \pm 0.00^{\mathrm{a}}$ & $0.27 \pm 0.00^{\mathrm{b}}$ \\
\hline RDA (\%) & 6.27 & 2.45 \\
\hline $\mathrm{Mg}$ & $36.51 \pm 0.00^{\mathrm{a}}$ & $33.88 \pm 0.25^{\mathrm{a}}$ \\
\hline RDA (\%) & 8.69 & 8.06 \\
\hline $\mathrm{Cu}$ & $0.10 \pm 0.00^{\mathrm{a}}$ & $0.06 \pm 0.00^{\mathrm{b}}$ \\
\hline RDA (\%) & 11.11 & 6.66 \\
\hline \multicolumn{3}{|c|}{$\begin{array}{l}{ }^{1} \text { Values are shown as means } \pm \text { standard deviation }(\mathrm{n}=3) . \text { Means followed by the same letter } \\
\text { within each line are not significantly different at } \mathrm{p}<0.05 \text {. Student's } \mathrm{t} \text { test. }{ }^{2} \mathrm{Recommendec} \\
\mathrm{Dietary} \text { Allowance }(\mathrm{RDA}) \text { for men }(31-50 \text { years): } \mathrm{Ca}=1000 \mathrm{mg} / \mathrm{day} ; \mathrm{Fe}=8 \mathrm{mg} / \mathrm{day} \\
\mathrm{Zn}=11 \mathrm{mg} / \mathrm{day} ; \mathrm{Mg}=420 \mathrm{mg} / \mathrm{day} ; \mathrm{Cu}=900 \mu \mathrm{g} / \mathrm{day} .{ }^{3} \text { Adequate Intake }(\mathrm{AI}) \text { for men } \\
(31-50 \text { years): } \mathrm{Na}=1.5 \mathrm{~g} / \text { day; } \mathrm{K}=4.7 \mathrm{~g} / \text { day. }\end{array}$} \\
\hline
\end{tabular}

(Marin et al., 2009). The contents of all analyzed minerals in the Amazon buritis were lower than those reported in the literature for buritis collected in the same region (Manhães \& Sabaa-Srur, 2011).

\subsection{Fatty acid composition}

The fruits from the analyzed regions showed different saturated, monounsaturated and polyunsaturated fatty acid concentrations (Table 4). The Amazon buriti presented the lowest saturated fatty acid contents. These values were lower than the ones reported by Costa et al. (2011) in the study of fatty acid contents of Brazilian nuts and fruit pulps and seeds. On the other hand, they presented the highest contents of monounsaturated fatty acids, similar to what has been reported in the literature $(76.0 \mathrm{~g} / 100 \mathrm{~g})$, for fruits from the same region (Darnet et al., 2011). However, for crude and refined Cerrado buriti oil, Aquino et al. (2012) obtained monounsaturated fatty acid values of $92.3 \mathrm{~g} / 100 \mathrm{~g}$, higher than the value found in the same type of buriti as that used in the present study.

Buriti fruits from both regions demonstrated considerable monounsaturated fatty acid contents, especially of oleic fatty acid. These contents were similar to extra virgin olive oil (70 to $80 \%)$, as described by Cicerale et al. (2009). Santos et al. (2013) observed in fruits of native palm belonging to the Arecaceae family (bacaba, inajá, pupunha and tucumã), collected in Amazon region, lower oleic fatty acid contents (ranging from $39.2 \mathrm{~g} / 100 \mathrm{~g}$ to $64.7 \mathrm{~g} / 100 \mathrm{~g}$ ), than in buriti analysed in present study.

Oleic fatty acid is regarded as having increased nutritional quality, since it can contribute to cholesterolemic control (Jenkins et al., 2002). Moreover, the low concentration of polyunsaturated fatty acids gives the buriti oil greater oxidative
Table 4. Fatty acid composition of buriti fresh pulp from two biomes of Brazil.

\begin{tabular}{lcc}
\hline \multicolumn{1}{c}{ Fatty acids } & \multicolumn{2}{c}{ Biome } \\
\cline { 2 - 3 } \multicolumn{1}{c}{ g/100 g of lipids) ${ }^{1}$} & Cerrado (Goiás) & Amazon (Pará) \\
\hline Saturated & $\mathbf{2 1 . 6 8} \pm \mathbf{0 . 0 0 7 0}{ }^{\mathrm{a}}$ & $\mathbf{1 7 . 2 7} \pm \mathbf{0 . 0 1 3 2}{ }^{\mathrm{b}}$ \\
Lauric C12:0 & $0.05 \pm 0.0024$ & $0.03 \pm 0.001$ \\
Myristic C14:0 & $0.15 \pm 0.0009$ & $0.07 \pm 0.0004$ \\
Pentadecanoic C15:0 & $0.05 \pm 0.0052$ & $0.06 \pm 0.0146$ \\
Palmitic C16:0 & $18.85 \pm 0.0374$ & $15.20 \pm 0.0183$ \\
Heptadecanoic C17:0 & $0.17 \pm 0.0076$ & $0.15 \pm 0.0008$ \\
Stearic C18:0 & $2.10 \pm 0.0462$ & $1.56 \pm 0.0018$ \\
Arachidic C20:0 & $0.16 \pm 0.0005$ & $0.10 \pm 0.0010$ \\
Behenic C22:0 & $0.06 \pm 0.0085$ & $0.04 \pm 0.0015$ \\
Lignoceric C24:0 & $0.09 \pm 0.0080$ & $0.06 \pm 0.0020$ \\
Monounsaturated & $\mathbf{7 3 . 0 3} \pm \mathbf{0 . 0 1 3 0}{ }^{\mathrm{b}}$ & $\mathbf{7 9 . 4 3} \pm \mathbf{0 . 0 2 1 9}$ \\
Oleic C18:1 cis w-9 & $72.21 \pm 0.0134$ & $78.57 \pm 0.0223$ \\
Palmitoleic C16:1 & $0.27 \pm 0.0010$ & $0.42 \pm 0.0004$ \\
Gadoleic C20:1 & $0.55 \pm 0.0014$ & $0.44 \pm 0.0006$ \\
Polyunsaturated & $\mathbf{5 . 2 9} \pm \mathbf{0 . 0 1 5 5}{ }^{\mathrm{a}}$ & $\mathbf{3 . 3 0} \pm \mathbf{0 . 0 0 8 8}$ \\
Linoleic $(\omega-6)$ C18:2 & $3.17 \pm 0.0058$ & $1.85 \pm 0.0023$ \\
Linolenic $(\omega-3)$ C18:3 & $2.12 \pm 0.0097$ & $1.45 \pm 0.0065$ \\
\hline
\end{tabular}

${ }^{1}$ Values are shown as means \pm standard deviation $(n=3)$. Means followed by the same letter within each line are not significantly different at $\mathrm{p}<0.05$. Student's t-test.

stability (Silva et al., 2009). In this context, it is still important to investigate the possible use of buriti fruits as an alternative source of vegetable oil.

In conclusion, the region of origin was seen to influence the physical and nutritional characteristics of buriti fruits. The fruits grown in the savannah region, with the tropical climate, more agreeable temperatures and elevated altitudes of the Cerrado biome, showed better performance in physical aspects, being larger and heavier. Nevertheless, higher contents of proteins, lipids, carbohydrates, monounsaturated fatty acids and iron were verified in the fruits native to a dense forest, with equatorial climate, higher temperatures, lower altitude and increased pluviometric index, as is found in the Amazon biome. Higher nutritional potential of buriti from both regions may be related to the high contents of good nutritional quality lipids, in addition to being regarded as a source of dietary fiber.

\section{References}

Aquino, J. S., Pessoa, D. C. N. P., Araújo, K. L. G. V., Epaminondas, P. S., Schuler, A. R. P., Souza, A. G., \& Stamford, T. L. M. (2012). Refining of buriti oil (Mauritia flexuosa) originated from the Brazilian Cerrado: physicochemical, thermal-oxidative and nutritional Implications. Journal of the Brazilian Chemical Society, 23(2), 212-219.

American Oil Chemists' Society - AOCS. (2009). Official methods and recommended practices of the American Oil Chemists' Society. Champaign: American Oil Society.

Association of Official Analytical Chemists - AOAC. (1998). Official methods of analysis. Washington: AOAC International.

Association of Official Analytical Chemists - AOAC. (2005). Official methods of analysis of the Association of Official Analytical Chemists (18th ed.). Gaithersburg: AOAC International. 
Barbosa, R. I., Lima, A. D., \& Mourão-Junior, M. (2010). Biometria de frutos de buriti (Mauritia flexuosa L. F. - Arecaceae): produção de polpa e óleo em uma área de savana em Roraima. Revista Amazônia Ciência e Desenvolvimento, 5(10), 71-85.

Bataglion, G. A., Silva, F. M. A., Eberlin, M. N., \& Koolen, H. H. F. (2014). Simultaneous quantification of phenolic compounds in buriti fruit (Mauritia flexuosa L.f.) by ultra-high performance liquid chromatography coupled to tandem mass spectrometry. Food Research International, 66, 396-400.

Bligh, E. G., \& Dyer, W. J. (1959). A rapid method of total lipid extraction and purification. Canadian Journal of Biochemistry and Physiology, 37(8), 911-917. PMid:13671378.

Borges, G. S. C., Vieira, F. G. K., Copetti, C., Gonzaga, L. V., Zambiazi, R. C., Mancini Filho, J., \& Fett, R. (2011). Chemical characterization, bioactive compounds, and antioxidant capacity of jussara (Euterpe edulis) fruit from the Atlantic Forest in southern Brazil. Food Research International, 44(7), 2128-2133.

Candido, T. L. N., Silva, M. R., \& Agostini-Costa, T. S. (2015). Bioactive compounds and antioxidant capacity of buriti (Mauritia flexuosa L.f.) from the Cerrado and Amazon biomes. Food Chemistry, 177(15), 313-319. PMid:25660891.

Canuto, G. A. B., Xavier, A. A. O., Neves, L. C., \& Benassi, M. T. (2010). Caracterização físico-química de polpas de frutos da Amazônia e sua correlação com a atividade anti-radical livre. Revista Brasileira de Fruticultura, 32(4), 1196-1205.

Cicerale, S., Conlan, X. A., Sinclair, A. J., \& Keast, R. S. J. (2009). Chemistry and health of olive oil phenolics. Critical Reviews in Food Science and Nutrition, 49(3), 218-236. PMid:19093267.

Costa, P. A., Ballus, C. A., Teixeira-Filho, J., \& Godoy, H. T. (2011). Fatty acids profile of pulp and nut of Brazilian fruits. Ciência e Tecnologia de Alimentos, 31(4), 950-954.

Darnet, S. H., Silva, L. H. M., Rodrigues, A. M. C., \& Lins, R. T. (2011). Nutritional composition, fatty acid and tocopherol contents of buriti (Mauritia flexuosa) and patawa (Oenocarpus bataua) fruit pulp from the Amazon region. Ciência e Tecnologia de Alimentos, 31(2), 488-491.

Ekholm, P., Reinivuo, H., Mattila, P., Pakkala, H., Koponen, J., Happonen, A., Hellstrom, J., \& Ovaskainen, M. L. (2007). Changes in the mineral and trace element contents of cereals, fruits and vegetables in Finland. Journal of Food Composition and Analysis, 20(6), 487-495.

Hartman, L., \& Lago, R. (1973). Rapid preparation of fatty acid methyl esters from lipids. Laboratory Practice, 22(6), 475-476. PMid:4727126.

Iglesias, I., Echeverría, G., \& Lopez, M. L. (2012). Fruit color development, anthocyanin content, standard quality, volatile compound emissions and consumer acceptability of several 'Fuji' apple strains. Scientia Horticulturae, 137, 138-147.

Institute of Medicine - IOM. (2006). Dietary Reference Intakes research synthesis: workshop summary. Washington: The National Academies Press.

Institute of Medicine - IOM. Food and Nutrition Board. (2011). Dietary Reference Intakes for calcium and vitamin D. Washington: The National Academies Press.

Instituto Nacional de Meteorologia - INMET. (2012). Banco de Dados Meteorológicos para Ensino e Pesquisa (BDMEP). Brasília: INMET. Retrieved from http://www.inmet.gov.br/portal/

Jenkins, D. J., Kendall, C. W., Marchie, A., Parker, T. L., Connelly, P. W., Qian, W., Haight, J. S., Faulkner, D., Vidgen, E., Lapsley, K. G., \&
Spiller, G. A. (2002). Dose response of almonds on coronary heart disease risk factors: blood lipids, oxidized low-density lipoproteins, lipoprotein(a), homocysteine, and pulmonary nitric oxide: a randomized, controlled, crossover trial. Circulation, 106(11), 13271332. PMid:12221048.

Koolen, H. H. F., Silva, F. M. A., Gozzo, F. C., Souza, A. Q. L., \& Souza, A. D. L. (2013). Antioxidant, antimicrobial activities and characterization of phenolic compounds from buriti (Mauritia flexuosa L. f.) by UPLC-ESI-MS/MS. Food Research International, 51(2), 467-473.

Liu, X., Zhao, M., Wang, J., Yang, B., \& Jiang, Y. (2008). Antioxidant activity of methanolic extract of emblica fruit (Phyllanthus emblica L.) from six regions in China. Journal of Food Composition and Analysis, 21(3), 219-228.

Liu, Y., Heying, E., \& Tanumihardjo, S. A. (2012). History, global distribution, and nutritional importance of citrus fruits. Comprehensive Reviews in Food Science and Food Safety, 11(6), 530-545.

Lorenzi, H., Souza, H.M., Costa, J.T.M., Cerqueira, L.S.C., \& Ferreira, E. (2004). Palmeiras brasileiras e exóticas cultivadas. Nova Odessa: Plantarum.

Manhães, L. R. T., \& Sabaa-Srur, A. U. O. (2011). Centesimal composition and bioactive compounds in fruits of buriti collected in Pará. Ciência e Tecnologia de Alimentos, 31(4), 856-863.

Marin, A. M. F., Siqueira, E. M. A., \& Arruda, S. F. (2009). Minerals, phytic acid and tannin contents of 18 fruits from the Brazilian savanna. International Journal of Food Sciences and Nutrition, 60(7), 180-190. PMid:19353365.

McGuire, R. G. (1992). Reporting of objective color measurements. HortScience, 27(12), 1254-1255.

Melo, W. S., Pena, R. S., Rodrigues, A. M. C., \& Silva, L. H. M. (2011). Hygroscopic behavior of buriti (Mauritia flexuosa) fruit. Ciência e Tecnologia de Alimentos, 31(4), 935-940.

Oliveira, A. L., Almeida, E., Silva, F. B. R., \& Nascimento, V. F. Fo. (2006). Elemental contents in exotic Brazilian tropical fruits evaluated by energy dispersive x-ray fluorescence. Scientia Agricola, 63(1), 82-84.

Pineli, L., Oliveira, G., Mendonça, M., Borgo, L., Freire, E., Celestino, S., Chiarello, M., \& Botelho, R. (2015). Tracing chemical and sensory characteristics of baru oil during storage under nitrogen. LWT - Food Science and Technology, 62(2), 976-982.

Rodriguez-Amaya, D. B., Kimura, M., Godoy, H. T., \& Amaya-Farfan, J. (2008). Updated Brazilian database on food carotenoids: factors affecting carotenoid composition. Journal of Food Composition and Analysis, 21(6), 445-463.

Sanjinez-argandoña, E. J., \& Chuba, C. A. M. (2011). Caracterização biométrica, física e química de frutos da palmeira bocaiuva Acrocomia aculeata (Jacq) Lodd. Revista Brasileira de Fruticultura, 33(3), 1023-1028.

Santos, M. F. G., Marmesatb, S., Brito, E. S., Alves, R. E., \& Dobarganesb, M. C. (2013). Major components in oils obtained from Amazonian palm fruits. Grasas y Aceites, 64(3), 328-334.

Silva, M. R., Lacerda, D. B. C. L., Santos, G. G., \& Martins, D. M. O. (2008). Caracterização química de frutos nativos do Cerrado. Ciência Rural, 38(6), 1790-1793.

Silva, S. M., Sampaio, K. A., Taham, T., Rocco, S. A., Ceriani, R., \& Meirelles, A. J. A. (2009). Characterization of oil extracted from buriti fruit (Mauritia flexuosa) grown in the Brazilian Amazon region. Journal of the American Oil Chemists' Society, 86(7), 611-616. 